\title{
Rhodocista pekingensis sp. nov., a cyst-forming phototrophic bacterium from a municipal wastewater treatment plant
}

\author{
Demin Zhang, Huifang Yang, Wei Zhang, Zhiyong Huang \\ and Shuang-Jiang Liu \\ Institute of Microbiology, Chinese Academy of Sciences, Beijing 100080, P. R. China
}

Correspondence

Shuang-Jiang Liu

shuangjiang@hotmail.com

\begin{abstract}
A novel bacterial species, Rhodocista pekingensis sp. nov., was isolated from a municipal wastewater treatment plant and characterized by polyphasic taxonomy. Cells of $R$. pekingensis were Gram-negative, motile by a single polar flagellum, vibrioid to spiral, $0 \cdot 6-0 \cdot 8 \mu \mathrm{m}$ in width and $0.8-1.5 \mu \mathrm{m}$ in length. R-bodies were not observed. Phototrophically grown cells contained lamellar photosynthetic membranes and bacteriochlorophyll a. Cell growth was anaerobically phototrophic or aerobically chemoheterotrophic. Anaerobically grown cultures were pink-reddish. Thiamin and vitamin $B_{12}$, but not biotin, were required for growth and $0.05 \%$ yeast extract stimulated growth. Acetate, lactate, pyruvate and succinate supported growth. Cysts were formed when butyrate was used as the sole carbon source. Molecular hydrogen $\left(\mathrm{H}_{2}\right)$, but not sulfide or thiosulfate, was used as an electron donor. The major cellular quinone was Q-9. The DNA $\mathrm{G}+\mathrm{C}$ content of cells was $68.8 \mathrm{~mol} \%$. The type strain of Rhodocista pekingensis is 3-p $\mathrm{p}^{\top}$ $\left(=\right.$ AS $1.2194^{\top}=$ JCM $\left.11669^{\top}\right)$.
\end{abstract}

\section{INTRODUCTION}

Many phototrophic purple non-sulfur bacteria show two modes of growth: either anaerobic phototrophy under light conditions or aerobic chemotrophy in the dark (Imhoff \& Trüper, 1989). This facultative nature of phototrophic purple non-sulfur bacteria has led to their widespread distribution in rivers, lakes, oceans and soil. Phototrophic bacteria play important roles in the bioconversion of organic matters and the biocycling of elements such as carbon, nitrogen and sulfur in these environments. Phototrophic purple non-sulfur bacteria are also commonly isolated from wastewater treatment plants (Hiraishi \& Ueda, 1994 and references cited therein). Because of their diverse metabolisms, they have been exploited in various wastewater treatment systems.

Spiral-shaped phototrophic purple non-sulfur bacteria were included in the genus Rhodospirillum (Trüper \& Imhoff, 1989) before the proposal of the species Rhodocista centenaria (Kawasaki et al., 1992) and Rhodospira trueperi (Pfennig et al., 1997). As more phototrophic bacterial strains were isolated and more information on the phenotypes and genotypes (particularly 16S rDNA sequences) of these and other previously described strains became

Published online ahead of print on 20 December 2002 as DOI 10.1099/ijs.0.02500-0.

The GenBank/EMBL/DDBJ accession number for the 16S rDNA sequence of strain $3-p^{\top}$ is AF523824. available, it was evident that the original description of the genus Rhodospirillum needed to be revised (Kawasaki et al., 1993). The establishment of the genus Rhodocista was based mainly on the results of $16 \mathrm{~S}$ rDNA sequences and also on its unique cyst-producing morphology and cellular quinone (Q-9). Until now, $R$. centenaria has been the only species of the genus Rhodocista and the type strain, ATCC $43720^{\mathrm{T}}$, was isolated from hot springs in Wyoming, USA (Favinger et al., 1989). In this paper, we describe an isolate from the Beijing municipal wastewater treatment plant, P. R. China. The isolate was characterized as a mesophilic, phototrophic bacterium that produces cysts and possesses Q-9 as the major quinone. Phylogenetic and phenotypic characterization of this isolate indicated that it is a novel species of the genus Rhodocista, for which the name Rhodocista pekingensis is proposed.

\section{METHODS}

Bacterial strains, media and cultivation. Strain $3-\mathrm{p}^{\mathrm{T}}$ was isolated from the Gao-Bei-Dian municipal wastewater treatment plant in Beijing, which is the main facility for the treatment of sewage from Beijing (a city with more than 10 million inhabitants). Rhodocista centenaria (also named Rhodospirillum centenum) ATCC $43720^{\mathrm{T}}$ was kindly provided by Professor Carl Bauer, Indiana University, USA.

Media used in this study were modified from the AT medium described by Imhoff \& Trüper (1992). ATB medium was made with butyrate as the sole carbon source. ATY medium was prepared by addition of $0.05 \%$ yeast extract and removal of sodium hydrogen carbonate from 
AT medium. ATYP medium was created by addition of $0.03 \%$ peptone to ATY medium. Agar plates were prepared by addition of $1.5 \%$ agar to the medium. Soft agar was made by reducing the amount of agar to $0 \cdot 7 \%$.

Routine cultivation was done anaerobically in screw-capped tubes or bottles filled with medium. Incubation was conducted at $34-41{ }^{\circ} \mathrm{C}$ under incandescent illumination of 1000-2000 lx.

Isolation. Samples of activated sludge were obtained from the municipal wastewater treatment plant located in Beijing, China. Samples were diluted and inoculated into soft-agar tubes, which were then incubated anaerobically in the light. After 1 week cultivation, the pink-reddish colonies were picked and streaked onto agar plates. The plates were placed in anaerobic jars, which were filled with argon and incubated under illumination. This was repeated three to five times to ensure purity of the culture.

Microscopy. Morphology and ultrastructure of cells grown under illumination were observed by optical microscopy (BH-2; Olympus) and by scanning and transmission electron microscopy (S-570 and H-600, respectively; Hitachi).

Absorption spectrum. Cells grown under illumination were harvested by centrifugation and resuspended in $60 \%$ sucrose solution. This suspension was used for determination of the absorption spectrum of intact cells. The absorption spectrum was recorded with spectrophotometers HP1050 (Hewlett Packard) for 300-820 nm, and Hitachi model 557 for $800-1200 \mathrm{~nm}$.

Physiological characterization. Tests for photoassimilation of organic substrates were performed in screw-capped tubes that contained ATY medium, as described by Imhoff \& Trüper (1989).

DNA base composition and DNA-DNA hybridization. Genomic DNA was extracted and purified according to the method of Marmur (1961), except for the addition of proteinase K in the SDS-treatment step. DNA base composition was determined by thermal denaturation (Marmur \& Doty, 1962). DNA-DNA hybridization was carried out as described by Tindall et al. (1984) with a minor modification: DNA fragments were labelled with $\alpha-{ }^{32} \mathrm{P}$, according to the instructions provided with the Nick Translation kit (Boehringer Mannheim).

Phylogenetic analysis. A fragment of $16 \mathrm{~S}$ rDNA was amplified and sequenced by using the MicroSeq 16S rDNA Gene kit and an ABI Prism 377 DNA Sequencer (both from Applied Biosystems) and primers $27 \mathrm{f}$ (5'-GAGAGTTTGATCCTGGCTCAG-3') and $1541 \mathrm{r}$ (5'-AAGGAGGTGATCCAGCC-3'). Sequence alignment and analysis of $16 S$ rRNA gene similarity were performed with the CLUSTAL W program (Thompson et al., 1994) and the SEQBOOT, DNADIST, NEIGHBOR and CONSENSE programs of the PHYLIP package, version 3.5c (Felsenstein, 1993).

Quinone determination. Quinones were determined as described by Collins (1985) and $\mathrm{Wu}$ et al. (1989). The bacterial pellet was lyophilized and treated with chloroform/methanol $(2: 1, \mathrm{v} / \mathrm{v})$. The quinones were separated on a 254 GF silica plate (Tsingdao Marine Chemical Corporation, China) with n-hexane/ethyl ether $(34: 6, \mathrm{v} / \mathrm{v})$ as the developing solvent. The number of isoprene units and the relative percentage of components of quinones were determined by HPLC (HP1074; Hewlett Packard), using a Bondapak C18 column $(3.9 \times 300 \mathrm{~mm}$; Waters $)$. Rhodocista centenaria ATCC $43720^{\mathrm{T}}$ and quinone 10 (Q-10; commercial standard sample) were used as controls.

Nucleotide sequence accession numbers. The 16S rRNA gene sequences used for construction of the phylogenetic tree were from the Ribosomal Database Project (Maidak et al., 2001). The GenBank accession number for the $16 \mathrm{~S}$ rDNA sequence of strain $3-\mathrm{p}^{\mathrm{T}}$ is AF523824.

\section{RESULTS AND DISCUSSION}

\section{Morphology and ultrastructures}

Strain 3-p $\mathrm{p}^{\mathrm{T}}$ had Gram-negative, vibrioid or spiral cells. The cells were $0 \cdot 6-0 \cdot 8 \mu \mathrm{m}$ in width and $0 \cdot 8-1 \cdot 5 \mu \mathrm{m}$ in length (Fig. 1). The cells were motile by means of a single, polar flagellum (Fig. 1, top). Electron microscopy revealed that
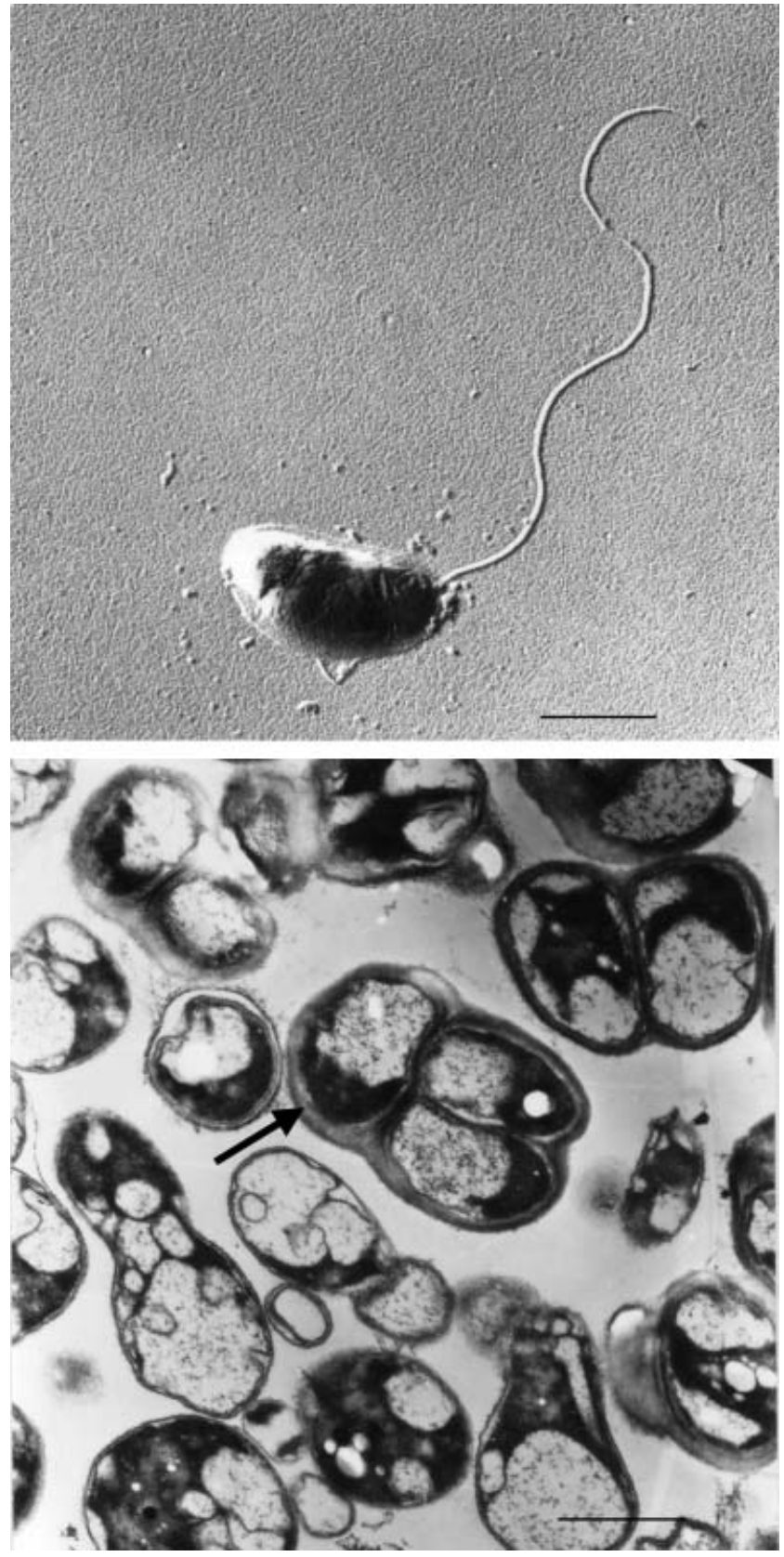

Fig. 1. Electron micrographs to show the morphology and cysts of Rhodocista pekingensis. Top, single polar flagellum; bottom, cysts formed during cultivation with ATB medium. Bars, $1 \mu \mathrm{m}$. 
phototrophically grown cells formed intracytoplasmic membranes of the lamellar type, which were parallel to the cytoplasmic membrane. Cysts were produced under aerobic incubation in the dark, when grown with butyrate as the sole carbon source (Fig. 1, bottom). Unlike Rhodocista centenaria, no R-body was observed in cells of strain $3-\mathrm{p}^{\mathrm{T}}$.

\section{Photopigments and quinones}

Colonies formed under either aerobic dark or anaerobic light conditions were pink. Liquid cultures were also pink when grown anaerobically under illumination. When incubated under aerobic dark conditions, however, liquid cultures were colourless. Absorbance maxima of phototrophically grown cells were $378,516,548,594,798$ and $885 \mathrm{~nm}$, which is indicative of the presence of bacteriochlorophyll $a$ and pigments of the spirilloxanthin series. Examination of lipid extracts of lyophilized cells revealed that the predominant quinone was Q-9, with minor amount of Q-10. No menaquinone was detected.

\section{Growth, physiological and biochemical characteristics}

Strain 3-p ${ }^{T}$ was facultatively anaerobic and heterotrophic. When cultivated anaerobically in the light, strain $3-\mathrm{p}^{\mathrm{T}}$ grew at $25-44{ }^{\circ} \mathrm{C}$, with an optimum between 31 and $42^{\circ} \mathrm{C}$; this strain differs from Rhodocista centenaria in that the latter has an optimal growth temperature of $39-45^{\circ} \mathrm{C}$. The $\mathrm{pH}$ range for growth was $6 \cdot 5-8 \cdot 0$, with an optimum of $7 \cdot 0$. No growth was observed in medium with $3 \% \mathrm{NaCl}$. Thiamin and vitamin $B_{12}$ were required for growth. Yeast extract stimulated growth significantly. Pyruvate, lactate, acetate, glutamate, aspartate and succinate supported growth. Malate, citrate, tartrate, arginine, ethanol, glycerol, mannitol, gluconate, benzoate, formate, glucose and sucrose did not support growth. Molecular hydrogen $\left(\mathrm{H}_{2}\right)$, but not sulfide or thiosulfate, was used as an electron donor. Ammonium salts and glutamate were used as nitrogen sources. Sulfate was used as a sulfur source for growth.

The phenotypic differences between strain $3-\mathrm{p}^{\mathrm{T}}$ and Rhodocista centenaria are listed in Table 1. Briefly, strain $3-\mathrm{p}^{\mathrm{T}}$ assimilated succinate, needed thiamin for growth, had an optimal growth temperature between 31 and $42^{\circ} \mathrm{C}$ and no R-bodies were seen in cells, whereas Rhodocista centenaria did not assimilate succinate, needed biotin rather than thiamin for growth, had an optimal growth temperature of $39-45{ }^{\circ} \mathrm{C}$ and R-bodies did occur in cells.

\section{DNA G + C content, DNA-DNA hybridization and phylogenetic relationships}

The $\mathrm{G}+\mathrm{C}$ content of the genomic DNA for strain $3-\mathrm{p}^{\mathrm{T}}$ was $68.8 \mathrm{~mol} \%$. Strain $3-\mathrm{p}^{\mathrm{T}}$ showed $56 \%$ DNA-DNA hybridization to Rhodocista centenaria, which is lower than $70 \%$, a level generally accepted to distinguish species. A $1373 \mathrm{bp}$ fragment of the $16 \mathrm{~S}$ rDNA of strain $3-\mathrm{p}^{\mathrm{T}}$ was amplified and sequenced. This sequence was compared with a dataset that consisted of $16 \mathrm{~S}$ rRNA gene sequences
Table 1. Differential characteristics of strain $3-\mathrm{p}^{\top}$ and Rhodocista centenaria ATCC $43720^{\top}$

+, Good growth/positive; -, no growth/negative; ND, not done. Data for Rhodocista centenaria were obtained from Favinger et al. (1989), Stadtwald-Demchick et al. (1990) and Kawasaki et al. (1992). Both strain 3-p $\mathrm{p}^{\mathrm{T}}$ and Rhodocista centenaria ATCC $43720^{\mathrm{T}}$ are vibrioid to spiral in shape, positive for cyst production, have Q-9 as the major quinone, require cobalamin (vitamin $\mathrm{B}_{12}$ ) for growth, grow on acetate, lactate, pyruvate and butyrate, and do not grow on malate or tartrate.

\begin{tabular}{|c|c|c|}
\hline Characteristic & Strain $3-\mathrm{p}^{\mathrm{T}}$ & $\begin{array}{l}\text { Rhodocista } \\
\text { centenaria }\end{array}$ \\
\hline $\begin{array}{l}\text { Optimum growth } \\
\text { temperature }\left({ }^{\circ} \mathrm{C}\right)\end{array}$ & $31-42$ & $39-45$ \\
\hline Cell size $(\mu \mathrm{m})$ & $0.6-0.8 \times 0.8-1.5$ & $1 \cdot 0-2 \cdot 0 \times 3 \cdot 0$ \\
\hline R-body occurrence & - & + \\
\hline DNA G $+\mathrm{C}$ content $(\mathrm{mol} \%)$ & $68 \cdot 8$ & $69 \cdot 9$ \\
\hline Thiamin (vitamin $\mathrm{B}_{1}$ ) & Required & $\mathrm{ND}$ \\
\hline Biotin & Not required & Required \\
\hline Succinate & + & - \\
\hline
\end{tabular}

available from the RDP $(n=15)$, including 11 of purple non-sulfur bacteria and four of closely related nonphototrophs of the $\alpha$-subclass of the Proteobacteria. Among the phototrophic bacteria, strain $3-\mathrm{p}^{\mathrm{T}}$ was most closely related to Rhodocista centenaria ( $97 \%$ similarity). A phylogenetic tree was constructed on the basis of a corrected evolutionary distances matrix (Fig. 2). Strain $3-\mathrm{p}^{\mathrm{T}}$ formed a close cluster with the only species of the genus Rhodocista (Rhodocista centenaria) and two species of the genus Azospirillum (Azospirillum irakense and Azospirillum amazonense).

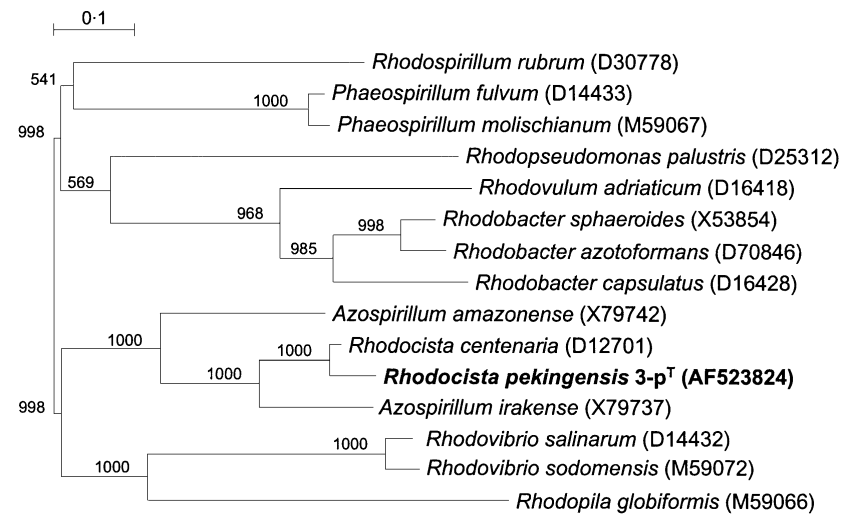

Fig. 2. Distance matrix tree showing phylogenetic relationships between the new isolate and related organisms. Confidence values obtained from 1000 bootstrap repetitions are given at branch-points. GenBank accession numbers are provided in parentheses after the species or strain names. Bar, $0.1 \%$ sequence divergence. 


\section{Description of Rhodocista pekingensis sp. nov.}

Rhodocista pekingensis (pe.king.en'sis. N.L. fem. adj. pekingensis pertaining to Peking, the former name of Beijing city, where the type strain was isolated).

Cells are vibrioid or spiral, $0 \cdot 6-0 \cdot 8 \mu \mathrm{m}$ wide and $0 \cdot 8-1.5 \mu \mathrm{m}$ long. Motile by means of a single polar flagellum. Gram-negative $\alpha$-Proteobacterium. Phototrophically grown cells contain intracytoplasmic lamellar membranes that are parallel to the cytoplasmic membrane. Thiamin and vitamin $\mathrm{B}_{12}$ are required for growth and $0.05 \%$ yeast extract stimulates growth. Anaerobically phototrophic or aerobically chemoheterotrophic. Pyruvate, lactate, acetate and succinate support growth. Malate, citrate, tartrate, arginine, ethanol, glycerol, gluconate, benzoate, formate, glucose, sucrose and mannitol do not support growth. Molecular hydrogen $\left(\mathrm{H}_{2}\right)$, but not sulfide or thiosulfate, is used as an electron donor. Cells contain Q-9. DNA G +C content is $68 \cdot 8 \mathrm{~mol} \%$.

The type strain, 3-p $\mathrm{p}^{\mathrm{T}}\left(=\right.$ AS $\left.1.2194^{\mathrm{T}}=\mathrm{JCM} 11669^{\mathrm{T}}\right)$, was isolated from a municipal wastewater treatment plant.

\section{ACKNOWLEDGEMENTS}

This work was supported by grants KSCX2-SW-102-05 and BRJH2000 from the Chinese Academy of Sciences (CAS). Provision of Rhodocista centenaria (Rhodospirillum centenum) ATCC $43720^{\mathrm{T}}$ by Professor Carl Bauer (Indiana University, USA) is highly appreciated. We express our thanks to Mr Xiao Changsong at the Institute of Microbiology, CAS, for his kind help during this research.

\section{REFERENCES}

Collins, M. D. (1985). Isoprenoid quinone analyses in classification and identification. In Chemical Methods in Bacterial Systematics, pp. 267-287. Edited by M. Goodfellow \& D. E. Minnikin. Orlando: Academic Press.

Favinger, J., Stadtwald, R. \& Gest, H. (1989). Rhodospirillum centenum, sp. nov., a thermotolerant cyst-forming anoxygenic photosynthetic bacterium. Antonie van Leeuwenhoek 55, 291-296.

Felsenstein, J. (1993). PHYLIP (phylogeny inference package), version 3.5c. Department of Genetics, University of Washington, Seattle, USA.
Hiraishi, A. \& Ueda, Y. (1994). Rhodoplanes gen. nov., a new genus of phototrophic bacteria including Rhodopseudomonas rosea as Rhodoplanes roseus comb. nov. and Rhodoplanes elegans sp. nov. Int J Syst Bacteriol 44, 665-673.

Imhoff, J. F. \& Trüper, H. G. (1989). Purple nonsulfur bacteria. In Bergey's Manual of Systematic Bacteriology, vol. 3, pp. 1658-1682. Edited by J. T. Staley, M. P. Bryant, N. Pfennig \& J. G. Holt. Baltimore: Williams \& Wilkins.

Imhoff, J. F. \& Trüper, H. G. (1992). The genus Rhodospirillum and related genera. In The Prokaryotes, 2nd edn, vol. 1, pp. 2141-2155. Edited by A. Balows, H. G. Trüper, M. Dworkin, W. Harder \& K. H. Schleifer. Heidelberg: Springer.

Kawasaki, H., Hoshino, Y., Kuraiski, Y. \& Yamasato, K. (1992). Rhodocista centenaria gen. nov., sp. nov., a cyst-forming anoxygenic photosynthetic bacterium and its phylogenetic position in the Proteobacteria alpha group. J Gen Appl Microbiol 38, 541-551.

Kawasaki, H., Hoshino, Y. \& Yamasato, K. (1993). Phylogenetic diversity of phototrophic purple non-sulfur bacteria in the Proteobacteria group. FEMS Microbiol Lett 112, 61-66.

Maidak, B. L., Cole, J. R., Lilburn, T. G. \& 7 other authors (2001). The RDP-II (Ribosomal Database Project). Nucleic Acids Res 29, 173-174.

Marmur, J. (1961). A procedure for the isolation of deoxyribonucleic acid from microorganisms. J Mol Biol 3, 208-218.

Marmur, J. \& Doty, P. (1962). Determination of the base composition of deoxyribonucleic acid from its thermal denaturation temperature. J Mol Biol 5, 109-118.

Pfennig, N., Lünsdorf, H., Süling, J. \& Imhoff, J. F. (1997). Rhodospira trueperi, gen. nov., sp. nov., a new phototrophic Proteobacterium of the alpha group. Arch Microbiol 168, 39-45.

Stadtwald-Demchick, R., Turner, F. R. \& Gest, H. (1990). Physiological properties of the thermotolerant photosynthetic bacterium, Rhodospirillum centenum. FEMS Microbiol Lett 67, 139-144.

Thompson, J. D., Higgins, D. G. \& Gibson, T. J. (1994). CLUSTAL W: improving the sensitivity of progressive multiple sequence alignment through sequence weighting, position-specific gap penalties and weight matrix choice. Nucleic Acids Res 22, 4673-4680.

Tindall, B. J., Ross, H. N. M. \& Grant, W. D. (1984). Natronobacterium gen. nov. and Natronococcus gen. nov., two new genera of haloalkaliphilic archaebacteria. Syst Appl Microbiol 5, 41-57.

Trüper, H. G. \& Imhoff, J. F. (1989). Genus Rhodospirillum. In Bergey's Manual of Systematic Bacteriology, vol. 3, pp. 1662-1666. Edited by J. T. Staley, M. P. Bryant, N. Pfennig \& J. G. Holt. Baltimore: Williams \& Wilkins.

Wu, C., Lu, X., Qin, M. \& Ruan, J. (1989). Analysis of quinone in cells of microorganisms by HPLC method. Microbiology (China) 16, 176-178. 